\title{
Evaluation of activated sludge treatment and settleability in remediation of edible oil effluent
}

\author{
K Reddy, GD Drysdale and F Bux* \\ Centre for Water and Wastewater Technology, Durban Institute of Technology, PO Box 953, Durban 4000, South Africa
}

\begin{abstract}
Wastewater discharged from the edible oil industry contains a very concentrated amalgamation of organic and inorganic materials making it a problematic effluent to treat. The aim of this study was to evaluate the activated sludge treatment of edible oil effluent from a sunflower oil processing company in KwaZulu-Natal. A 28 l laboratory-scale modified Ludzack-Ettinger (MLE) activated sludge process was used to treat refinery effluent from the industry. Pre-flocculation of the effluent was necessary to remove the bulk of the fats, oils and greases (FOG) prior to treatment. Routine analyses of chemical oxygen demand (COD), total nitrogen $(\mathrm{N})$, total phosphorus (TP), total suspended solids (TSS), dilute sludge volume index (DSVI) and FOG were conducted in conjunction with microscopic analyses of floc structure, filamentous bacteria and protozoa. An average COD removal of $81 \%$ was obtained for the flocculated effluent, at a $15 \mathrm{~d}$ sludge age and $24 \mathrm{~h}$ hydraulic retention time. However, significantly high TSS values were observed in the treated effluent as a result of sludge-oil aggregation, pin-point floc formation and high numbers of freeswimming bacteria. Microscopic analysis confirmed an absence of filamentous bacteria resulting in poor floc formation, subject to shearing. Periods of soybean oil effluent addition, however, resulted in sludge bulking with DSVI measurements as high as 770 $\mathrm{m} / \mathrm{g}$. Fluctuating protozoan populations were also correlated to fluctuating TSS values and were found to be negatively impacted by uncontrolled pre-flocculation.
\end{abstract}

Keywords: edible oil effluent, activated sludge settleability, protozoa filamentous bacteria

\section{Introduction}

The edible oil industry has a very high specific water intake compared to other industries in South Africa and releases as much as $40 \%$ of this water as effluent into municipal sewer systems (Steffen, Roberts and Kirsten, 1989). Edible oil effluents contain an amalgamation of high concentrations of fats, oils, sodium, phosphorus, sulphate and various other pollutants and owing to the large percentage of this effluent released into the sewer, treatment is essential prior to discharge (Hrudey, 1981; Horan, 1990). Untreated edible oil effluent is known to cause both physical and as shock loading problems to receiving wastewater treatment plants (Eroglu et al., 1990). In addition, current legislation in South Africa has made effluent treatment by the producer compulsory prior to discharge to municipal systems (The National Water Act, 1998).

Efficient treatment of edible oil effluent is usually achieved via a combination of physical, chemical and biological treatment processes (Dalzel, 1994). Common physical treatment processes include the use of fat traps and dissolved air flotation (DAF). However, while reasonable success can be achieved using physical separation, on-site applications of such processes (especially fat traps) are often limited and uneconomical and most often do not reduce fats, oils and grease (FOG) to below required standards (Grant, 1980; Eroglu et al., 1990; Dalzel, 1994). Chemical treatment of edible oil effluent is often used to enhance physical or biological treatment methods. The most common chemical methods applied are $\mathrm{pH}$ correction and flocculation/coagulation (Eroglu

\footnotetext{
* To whom all correspondence should be addressed.

푱 +2731 204 2346; fax: +2731 204 2778; e-mail: faizalb@dit.ac.za

Received 31 December 2002; accepted in revised form 14 April 2003.
}

et al., 1990; Dalzel, 1994; Lilley et al., 1997). Problems associated with chemical treatment processes are that the chemicals used are corrosive in nature and hence systems become expensive to operate (Lilley et al., 1997). Chemical treatment also results in increased mineralisation and salination of water, thus restricting reuse. Biological treatment of edible oil effluent is seen as a cost-effective and efficient alternative (Mkhize et al., 2000). Effluent may be treated aerobically, anaerobically by combining both approaches (Grant, 1980; Seng, 1980; Eroglu et al., 1990; Hui, 1996b). However, biological treatment of edible oil effluent has not received as much focus as physical and chemical treatment processes. Aerobic treatment, in particular, has possibly received the least attention.

The aim of the work reported here was, therefore, to assess biological treatment of edible oil effluent using activated sludge treatment. Particular emphasis was placed on COD reduction in addition to solids reduction (i.e. FOG and TSS). The effects of edible oil effluent treatment on sludge settleability, floc structure and activity of filamentous bacteria and protozoan populations were evaluated to determine the overall impact on total solids reduction.

\section{Experimental}

A laboratory-scale modified Ludzack-Ettinger (MLE) process was used to treat refinery effluent from a sunflower oil processing company in KwaZulu-Natal. MLE configuration was selected due to nitrogen dosing requirements for treatment of the edible oil effluent, subsequently resulting in aerobic nitrate production. The MLE system consisted of an $8 \ell$ anoxic reactor, two consecutive $10 \ell$ aerobic reactors and a $1.5 \ell$ clarifier, and was operated at $20^{\circ} \mathrm{C}$ at a hydraulic retention time of $24 \mathrm{~h}$ and $15 \mathrm{~d}$ sludge age. An arecycle (from the second aerobic reactor) was established at a 2:1 
ratio with the influent flow in conjunction with the s-recycle at a 1:1 ratio with the influent flow. Aerobic activated sludge was obtained from the Darvill Wastewater Works in Pietermaritzburg, KwaZuluNatal, as seed sludge. Sunflower seed oil effluent was collected every two weeks and stored at $4{ }^{\circ} \mathrm{C}$, prior to treatment, except for addition of one batch of soybean oil effluent from mid-July to the beginning of August. A commercial flocculent ( $\mathrm{C} 40$ - Chemserve Trio, Durban) was used for pretreatment of the refinery effluent to remove the bulk of the fats, oils and greases (FOG) prior to biological treatment. Failure to pretreat the oil effluent resulted in mechanical problems due to flotation of FOG, especially in the aerobic reactors. The $\mathrm{pH}$ of the flocculated influent was adjusted to 7 using hydrochloric acid or sodium hydroxide, and dosed with ammonium chloride and potassium dihydrogen orthophosphate to maintain the COD:N:P ratio at 100:5:1 (pre-flocculation reduced $\mathrm{N}$ and $\mathrm{P}$ content thus restricting COD removal - results not shown). Influent and effluent $\mathrm{COD}$, total $\mathrm{N}$ and total $\mathrm{P}$ were measured routinely using a Merck Nova Spectroquant and reagents specific for each test (Cat. Nos 1.14541, 1.14537 and 1.14729, respectively). Total suspended solids (TSS), dilute sludge volume index (DSVI) and FOG were also routinely monitored using Standard Methods (1989), in conjunction with microscopic analysis of floc structure, filamentous bacteria and protozoa (Eikelboom and Van Buijsen, 1981; Jenkins et al., 1993).

\section{Results}

The laboratory-scale MLE unit demonstrated an average COD removal efficiency of $81 \%$ (Fig. 1). The system demonstrated poor FOG removal as just $7 \%$ of the remaining FOG, after preflocculation, could be removed biologically (results not shown). High effluent TSS was noted continually throughout operation with very high readings being obtained during July to August (Fig. 2). The very high effluent TSS values observed in July to August coincided with both an episode of filamentous bulking (Fig. 3) and lack of pre-flocculation. High influent TSS values during this period are as a result of no pre-flocculation having taken place when the project ran out of flocculent (due to temporary supplier shortage), while all other periods of high influent TSS readings were due to over-flocculation (Fig. 2). With varying $\mathrm{pH}$ ranges between batches of collected effluent, flocculation procedures were adversely affected, resulting in excessive pre-flocculation and introduction of suspended solids, in the form of flocculent, into the laboratory-scale unit.

Microscopic evaluation of the activated sludge revealed dramatic shifts in floc structure with the onset of treatment of the sunflower seed oil effluent (Fig. 4). The Darvill seed sludge demonstrated a well-balanced floc structure, in relation to filamentous and floc-forming bacterial populations, which settled well with little obvious pin-point floc formation (Fig. 4A). Filamentous bacteria constituent in the seed sludge, were identified as Nostocoida Limocola I, Nostocoida Limocola II, Sphaerotilus natans, and Types 1851, 0675 and 0041. However, soon after treatment started, all filamentous bacteria disappeared from the system resulting in compact, pin-point floc formation and high numbers of free-swimming bacteria (Fig. 4C). Pin-point flocs and free-swimming bacteria continually contributed to high effluent TSS throughout treatment (Fig. 2). Very large, compact floc aggregates (150 to $170 \mu \mathrm{m})$ were also observed, which were as a result of oil and floc aggregation (Fig. 4B). DSVI measurements were very low throughout operation until July to August when episodes of filamentous bulking suddenly occurred with DSVI readings ranging from $200 \mathrm{me} / \mathrm{g}$ to as high as $770 \mathrm{~m} / \mathrm{g}$ (Figs. 2 and
4D). Concurrently, large amounts of biomass washout were observed (as can be seen by the effluent TSS results, Fig. 2) with temporary loss in COD reduction occurring (Fig. 1). Microscopic observation confirmed extensive inter-floc bridging with a Sphaerotilus sp. being largely predominant and Haliscomenobacter hydrossis, Sphaerotilus natans, Nostocoida limocola and Type 1851 present in low numbers.

Protozoa showed fluctuations in behaviour throughout operation with Vorticella sp. and Telotroch sp. predominating and Epistylus sp., testate amoeba, rotifers and nematodes in very low numbers (Fig. 5). Peaks in Telotroch sp. and testate amoeba numbers coincided with periods of excessive pre-flocculation, i.e. start-up period in March and then in June (Figs. 2 and 5). Vorticella sp. showed very consistent growth throughout operation, except during periods of excessive pre-flocculation (i.e. start-up in March and June), and peaked most in August during the bulking and absence of the pre-flocculation period (Figs. 2, 3 and 5). Epistylus sp., rotifers and nematodes were also present in very low numbers with no large peaks in population numbers ever occurring throughout the treatment (Fig. 5).

\section{Discussion}

Due to pre-flocculation of the refinery effluent, the COD remaining for biological treatment was largely soluble and very easily consumed by the activated sludge microflora ( $81 \%$ reduction). Very little, or no particulate COD was introduced to the unit and hence it is not clear, from this study, how efficiently activated sludge can remove particulate COD present in edible oil effluent. Particulate COD in edible oil effluents constitutes high concentrations of FOG. Poor FOG removal was noted in the MLE system as just 7\% of the remaining FOG, after pre-flocculation, could be removed biologically. Aerobic activated sludge systems do not have long retention times, as in anaerobic treatment, and therefore the microflora are not capable of breaking down FOG efficiently. In addition, microscopic observations indicated very poor floc formation in the MLE unit largely due to a lack of filamentous bacteria. Sludge flocs ranged from very large, compact oily aggregates to smaller, compact and pin-point flocs, as well as large numbers of free-swimming bacteria. Small compact flocs, pin-point flocs and free-swimming bacteria were the predominant floc structures observed due to the lack of filamentous 'backbone' in the sludge. The compact and small nature of the flocs would, while sufficient for soluble COD removal, be disadvantageous to particulate COD removal should pre-flocculation of the edible oil effluent be excluded. Small compact pin-point flocs and free-swimming bacteria lack the filtering ability to trap particulate materials suspended in wastewater (Eikelboom and Van Buijsen, 1981; Horan, 1990; Jenkins et al., 1993; Ekama et al., 1995; Wanner et al., 1998; Bitton, 1999). The bad floc structure may also have contributed to the very poor FOG removal seen, as the compact nature of the flocs would restrict contact between the insoluble FOG and most of the floc-forming organisms. Coupling of anaerobic treatment of FOG with aerobic treatment, would be a possible alternative for the comprehensive treatment of edible oil effluent, thereby eliminating shock-loading of receiving aerobic treatment installations.

High effluent TSS, noted continually throughout operation of the MLE unit, was seen to be related to both the poor floc structure as well as protozoan population behaviour. At inception, the Darvill seed sludge contained a diverse population of filamentous bacteria which disappeared quickly after the onset of treatment of the sunflower seed oil effluent. Imbalances between filamentous and floc-forming organisms have been correlated to activated 


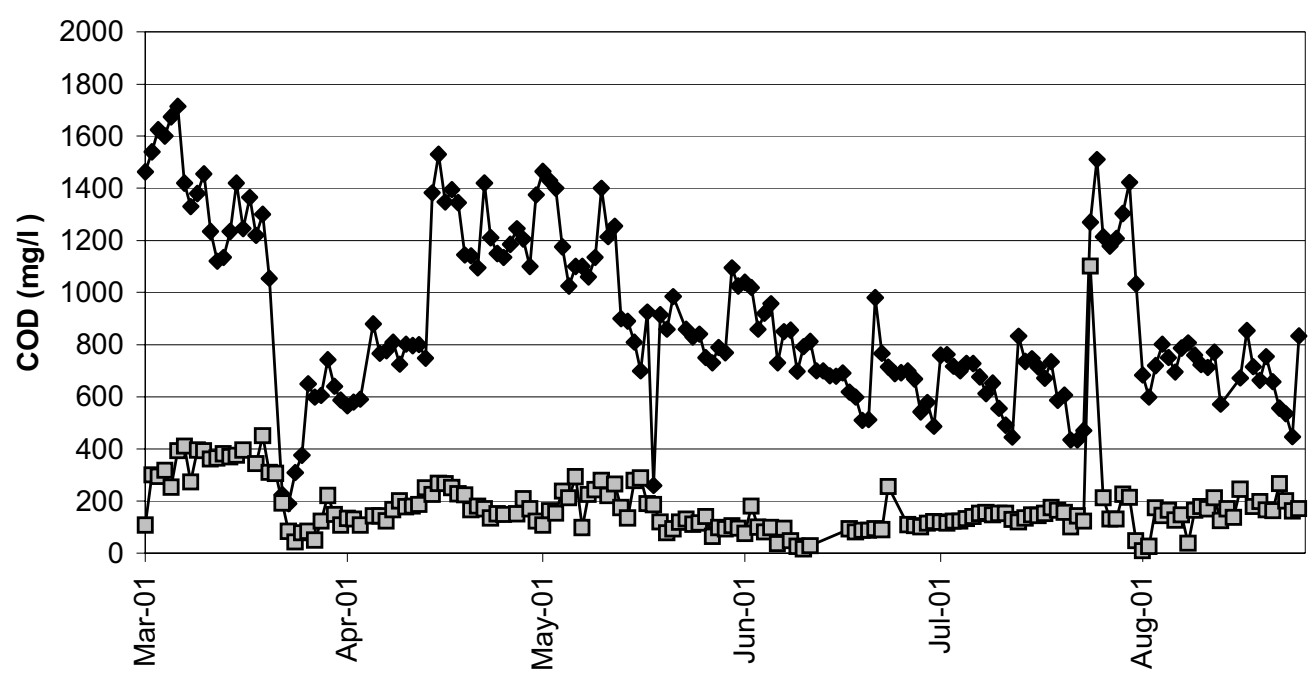

Time (days)

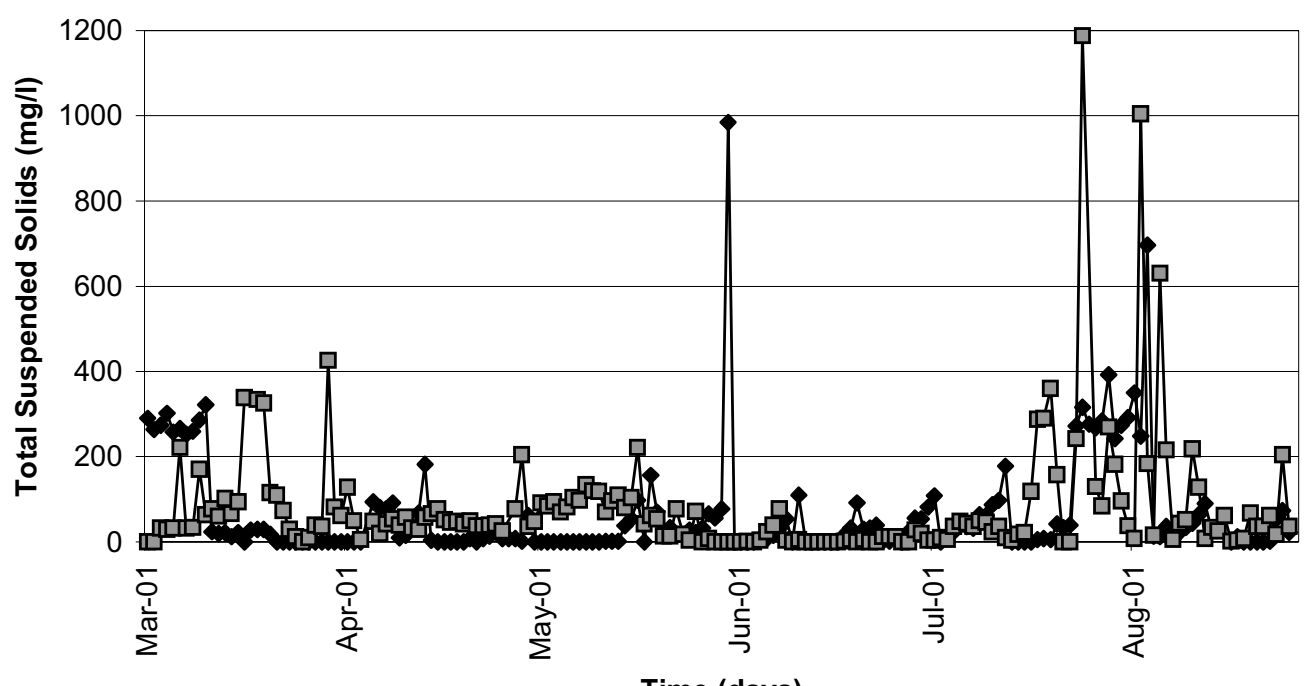

Time (days)

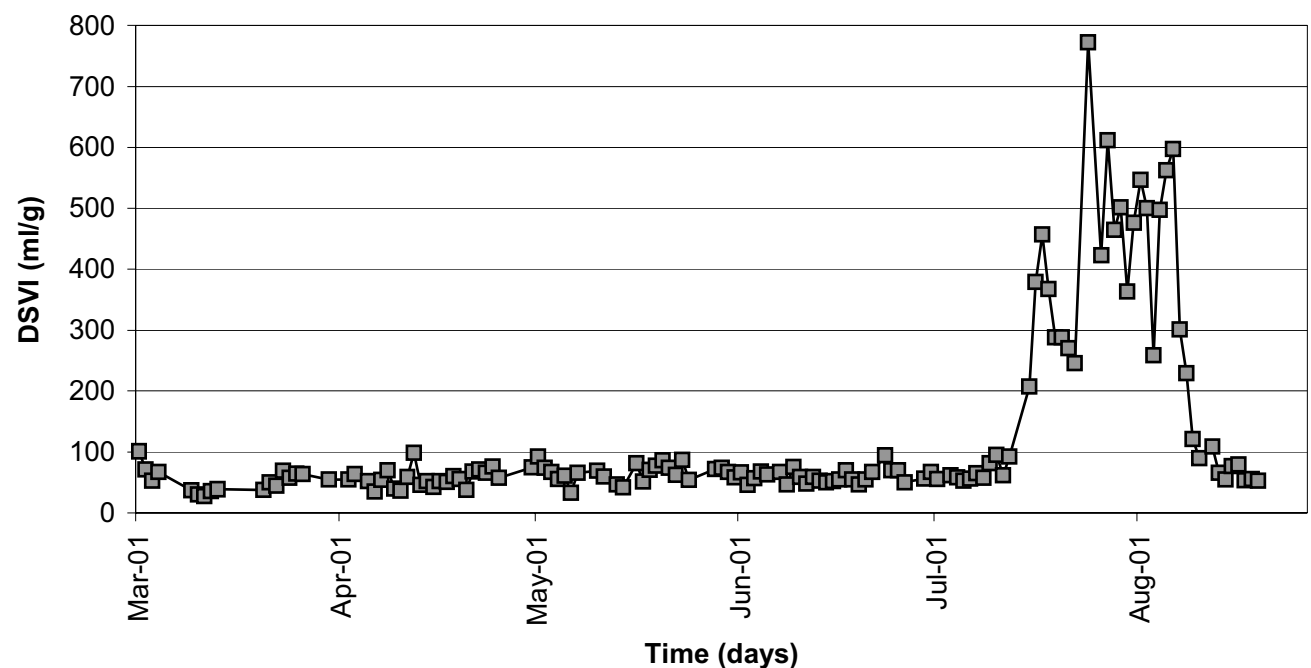

Figure 3

Mixed liquor dilute sludge volume index (DSVI) results for the laboratoryscale MLE unit treating edible oil refinery effluent
$C O D$ reduction for the laboratory-scale MLE unit treating edible oil refinery effluent

Figure 2

Influent and effluent total suspended solids (TSS) results for the laboratoryscale MLE unit treating edible oil refinery effluent sludge settleability as filamentous bacteria are important for the formation of robust flocs that are capable of withstanding agitation and aeration (Jenkins et al., 1993; Scuras et al., 1998). The lack of filamentous bacteria in the laboratory-scale unit was responsible for the formation of small compact and pin-point flocs due to mechanical shearing of weak sludge flocs. Along with large num-

bers of free-swimming bacteria, pin-point flocs were contributing to continually high effluent TSS. The large, compact aggregates of sludge observed were also incapable of trapping smaller particles due to their compact nature. In such instances large particles settle rapidly, while smaller particles (i.e. pin-point flocs and freeswimming bacteria) remain suspended or settle slowly (Eikelboom 
A

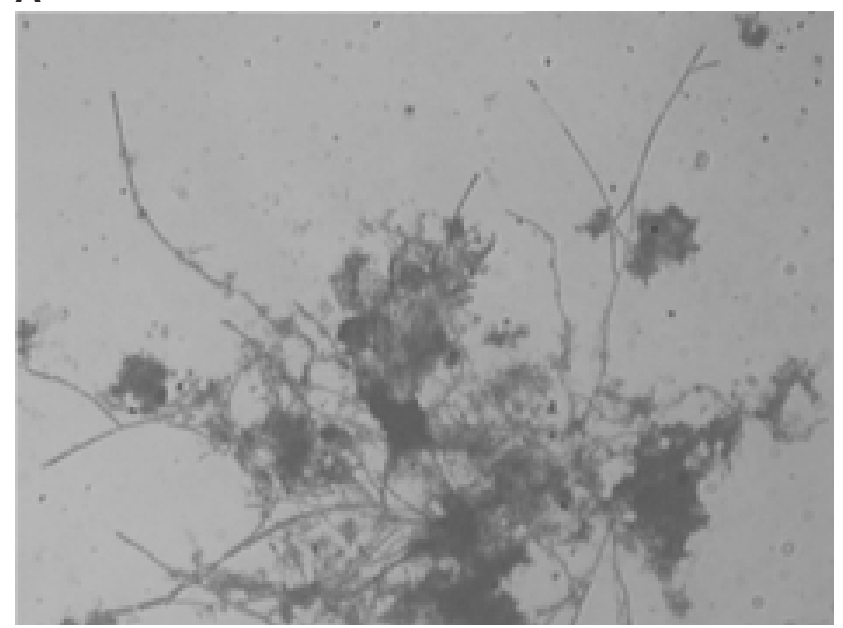

C

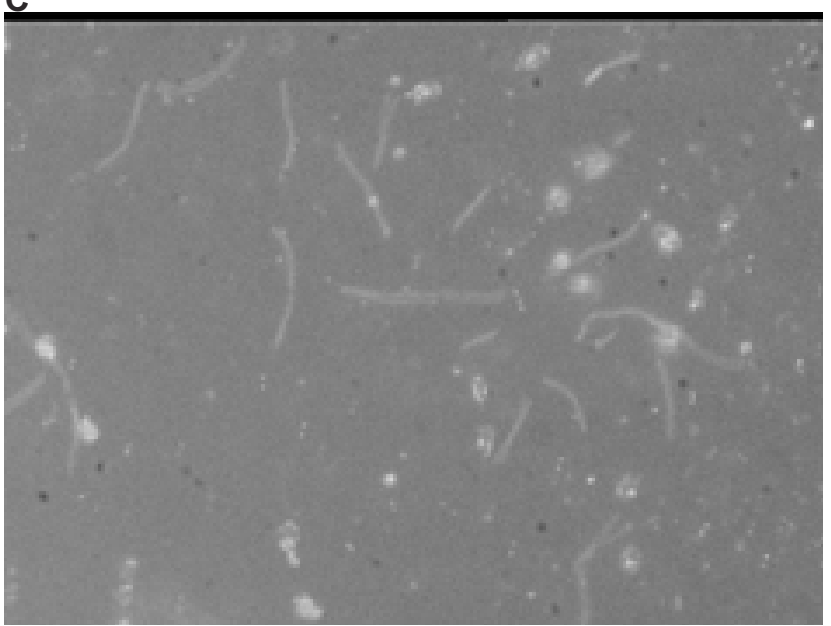

B

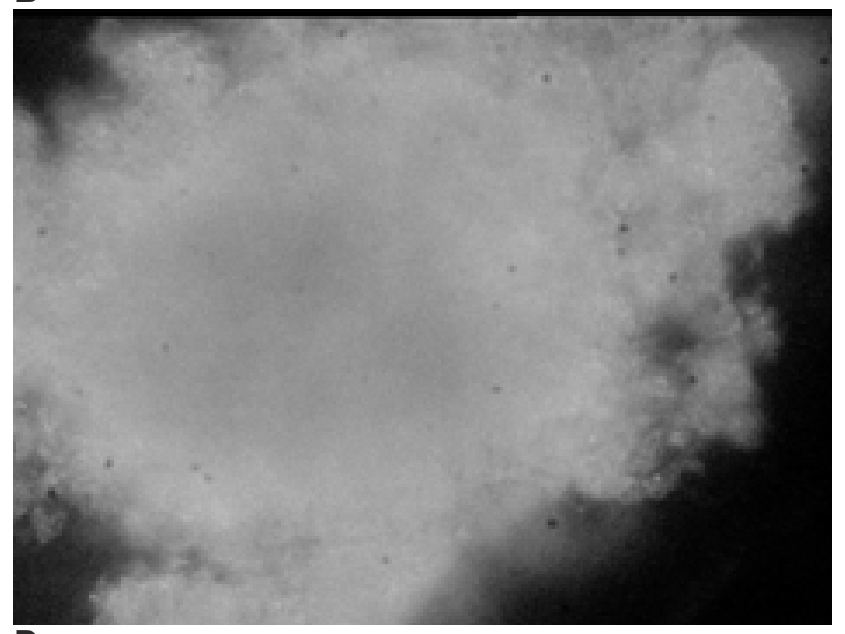

D

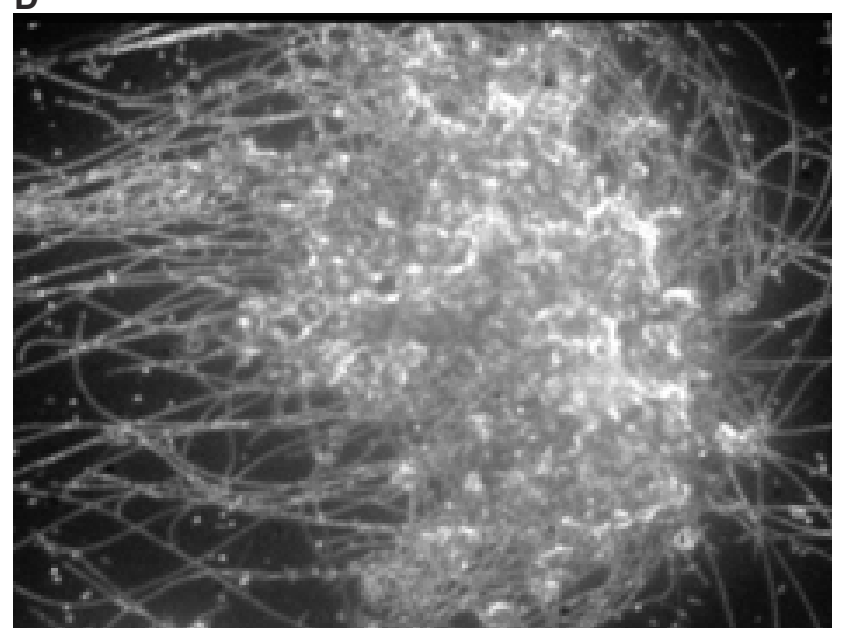

Figure 4

Microscopic changes observed in floc structure in the MLE unit treating edible oil effluent: A) Darvill seed sludge ( $\times 100$ mag., light); B) Large compact flocs treating sunflower seed oil effluent (×100 mag., dark field); C) Free-swimming bacteria resulting from pin-point floc formation during treatment of sunflower seed oil effluent (×1000 mag., dark field, oil im.); D) Sludge bulking occurring mid-July to early August during treatment of soybean oil effluent batch (×100 mag., dark field).

and Van Buijsen, 1981; Horan, 1990; Jenkins et al., 1993; Ekama et al., 1995; Wanner et al., 1998; Bitton, 1999). It is not certain as to what restricted filamentous growth during the treatment of the sunflower seed oil effluent. Toxic inhibition by organic and inorganic chemicals is a major problem affecting solids separation and sludge compaction properties during the biological treatment of industrial and domestic wastewaters (Bitton, 1999). However, lack of filamentous bacteria was not the only contribution to high TSS as was seen in July to August. Very high effluent TSS values observed over this period coincided with both an episode of filamentous bulking and lack of pre-flocculation. Washout of large amounts of biomass occurred due to the filamentous bulking with resultant high effluent TSS and temporary loss in COD removal efficiency at the peak of the bulking episode. Conditions such as low food to micro-organism (F/M) ratio, nutrient deficiency, low dissolved oxygen, low temperature and wastewater composition are all known to contribute to proliferation of filamentous bacteria at times (Bitton, 1999). While no changes were made to the operating parameters of the MLE unit, wastewater composition was hypothesised as the key factor responsible for inducing the filamentous bulking. Low F/M ratio was considered as a possibility due to the gradual reduction in influent COD noted from May until July when the bulking started. However, as the filamentous bulking occurred very suddenly without any gradual increase in filament numbers (routine microscopic observations), the lowering F/M ratio may not have been the causative, or sole causative, factor. The filamentous bulking was noted to coincide with both a new edible oil effluent batch as well as absence of pre-flocculation due to a shortage of flocculent $\mathrm{C} 40$ with the supplier. However, bulking started a few days before pre-flocculation had stopped (as can be seen by influent TSS results), therefore indicating that changes must have occurred in the edible oil effluent composition. Consultation with the edible oil processing company supplying the effluent revealed that intermittent refining of soy bean oil had commenced, in addition to the usual sunflower seed oil, at approximately the same time bulking in the laboratory-scale MLE unit began. It is not clear what components of the soybean oil effluent promoted filamentous growth as soybean and sunflower oils are relatively similar in composition with some components simply present in higher concentrations than others. In particular, the phosphatide content of the oils differ, the soybean oil containing far less than the sunflower oil (Hui, 1996a).

Protozoa also showed fluctuations in behaviour, throughout operation, that could be correlated to the effluent TSS. Vorticella 


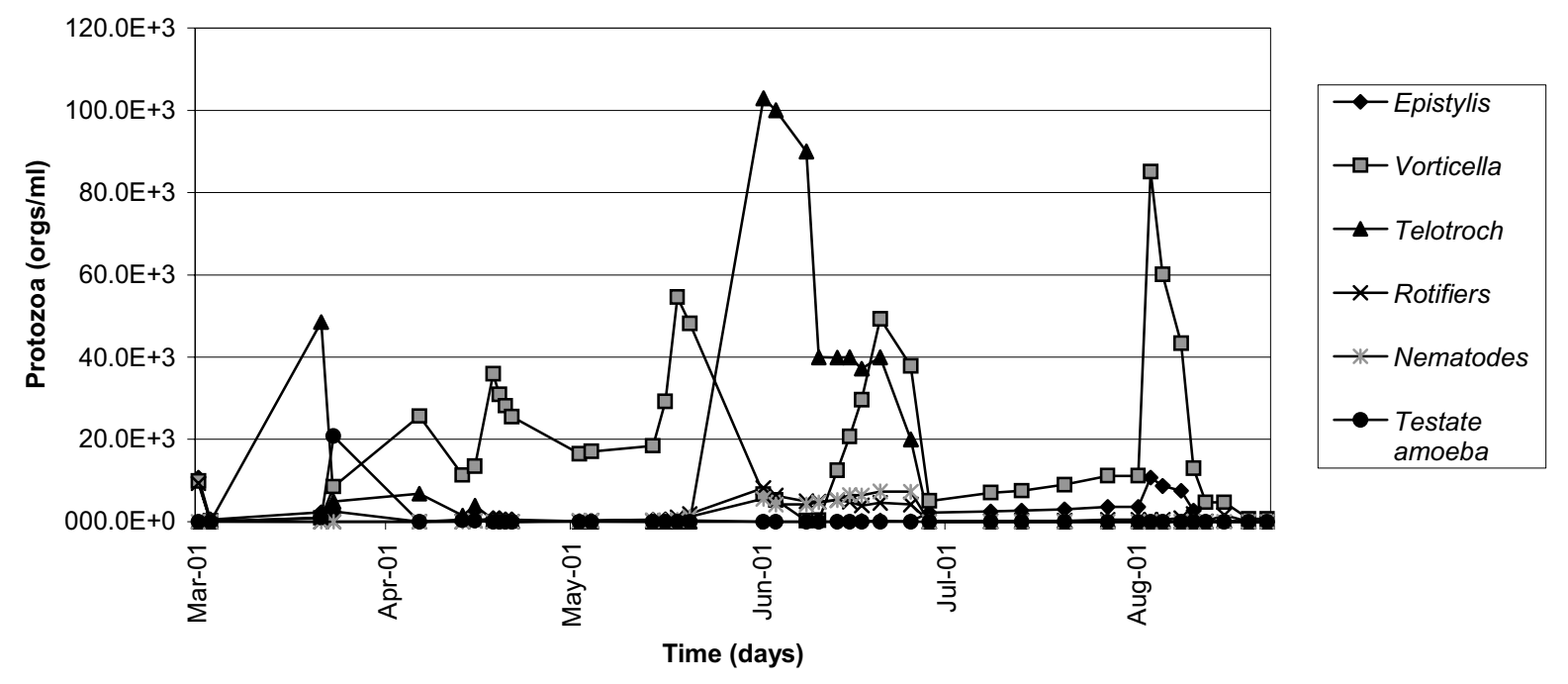

Figure 5

Protozoan population behaviour in the laboratory -scale MLE unit treating edible oil refinery effluent.

sp. and Telotroch sp. predominated in the MLE unit and showed distinctive high and low peaks at different points of operation. At start-up of the process in March all protozoan species showed a marked decline in numbers, possibly due to toxic shock from initial exposure to the edible oil effluent and excessive flocculation. Protozoa are excellent indicators of toxicity and are generally the first to react to the introduction of toxic substances to a treatment system (Eikelboom and Van Buijsen, 1981). At inception the flocculation procedure needed optimisation with early effluent batches being over-flocculated, resulting in unreacted flocculent entering the unit (as can be seen from elevated influent TSS readings). A period of protozoan acclimation was therefore seen, at start-up, with species succession occurring as time progressed. Telotroch $\mathrm{sp}$. and testate amoeba numbers were the first to increase in the system whereafter decreasing and being succeeded by the stalked ciliate, Vorticella sp. The presence of elevated Telotroch $\mathrm{sp}$. and testate amoeba numbers is indicative of toxic shock as these organisms are resistant to adverse conditions. Telotroch sp. again peaked during May to June, to their highest numbers seen throughout operation. This increase coincided with an accidental addition of excessive flocculent to the edible oil effluent, further substantiating this organism's resilience under adverse conditions. Varying $\mathrm{pH}$ ranges were noted between batches of collected effluent, which negatively impacted pre-flocculation (as can be seen by elevated influent TSS due to unreacted flocculent). The excessive flocculation was also noted to have a negative impact on Vorticella $\mathrm{sp}$. which, until this point (April to May), had predominated in the system. However, growth of Vorticella sp. was recovered shortly after the flocculation problem was resolved indicating that these stalked ciliates are not resistant to adverse conditions. Stalked ciliates, as well as some other protozoa, are very sensitive to changes and adverse conditions and usually die off rapidly during toxic shock loading. This has negative implications for suspended solids removal as protozoa, especially the stalked ciliates, are crucial for consuming free-swimming bacteria and hence maintaining low TSS (Eikelboom and Van Buijsen., 1981; Horan, 1990; Jenkins et al., 1993). The sensitivity of Vorticella sp. to the flocculent was further established during the bulking episode when no flocculation occurred (July to August). High influent TSS during this period was indicative of edible oil effluent solids entering the system due to insufficient flocculation. With reduced flocculent toxicity and high TSS due to bulking, Vorticella sp. peaked rapidly to their highest numbers seen during operation. This peak, however, decreased as soon as pre-flocculation recommenced. Epistylus sp., rotifers and nematodes were also present in very low numbers and had no significant effect on the system.

\section{Conclusion}

It is evident from the study that aerobic activated sludge treatment can reduce the soluble COD component of edible oil effluent while largely being incapable of efficient FOG removal. Coupling of anaerobic digestion of FOG with aerobic treatment, needs to be evaluated as a comprehensive method for the effective treatment of edible oil effluent. However, high effluent TSS experienced during aerobic treatment of sunflower seed oil effluent, was a persistent problem due to the lack of filamentous growth and subsequent poor floc formation. While it is uncertain as to which component of soybean oil effluent was responsible for inducing bulking, future work should focus on mixing sunflower seed and soybean oil effluents to obtain balanced filamentous populations and floc structure. This may be a successful alternative for the reduction of effluent TSS as well as for increasing COD removal. Protozoa also demonstrate fluctuations during biological treatment of edible oil effluent with uncontrolled pre-flocculation responsible for elevated effluent TSS. Excessive pre-flocculation needs to be avoided as this has toxic shock loading effects on protozoa, especially Vorticella sp. which predominated in the system, hence limiting protozoan grazing on free-swimming bacteria and pin-point flocs.

\section{Acknowledgements}

The researchers gratefully acknowledge the Water Research Commission and the National Research Foundation of South Africa for their joint support of the study.

\section{References}

BITTON G (1999) Wastewater Microbiology (2 ${ }^{\text {nd }}$ edn.). Wiley-Liss Inc., Canada.

DALZEL JM (1994) Food Industry and the Environment. Practical Issues and Cost Implications. Blackie Academic and Professional, UK. 
EIKELBOOM DH and VAN BUIJSEN HJJ (1981) Microscopic Sludge Investigation Manual ( $2^{\text {nd }}$ edn.). TNO Research Institute for Environmental Hygiene, The Netherlands.

EKAMA GA, CASEY TG, WENTZEL MC and MARAIS GvR (1995) Filamentous organism bulking in nutrient removal activated sludge systems. Paper 1: A historical overview of causes and control. Water SA 21 (3) 231-238.

EROGLU V, OZTURK I, SAN HA and DEMIR I (1990) Comparative evaluation of treatment alternatives for wastewaters from edible oil industry. Water Sci. Technol. 22 (9) 225-234.

GRANT PE (1980) Treatment of fatty effluents. In: Herzka A and Booth RG (eds.) Food Industry Wastes: Disposal and Recovery. Applied Science Publishers, UK.

HORAN NJ (1990) Biological Wastewater Treatment Systems Theory and Operation. John Wiley and Sons Inc., USA.

HRUDEY SE (1981) Activated sludge response to emulsified lipid loading. Water Res. 15 361-373.

HUI YH (1996a) Baileys Industrial Oil and Fat Products - Edible Oil \& Fat Products: Oils and Oil Seeds (Vol. 2, $5^{\text {th }}$ edn.). John Wiley and Sons Inc., USA.

HUI YH (1996b) Baileys Industrial Oil and Fat Products - Edible Oil \& Fat Products Processing Technology (Vol. 4, $5^{\text {th }}$ edn.). John Wiley and Sons Inc., USA.

JENKINS D, RICHARD MG and DAIGGER GT (1993) Manual on the Causes and Control of Activated Sludge Bulking and Foaming. Lewis Publishers Inc., USA.
LILLEY ID, PYBUS PJ and POWER SPB (1997) Operating Manual for Biological Nutrient Removal in Wastewater Treatment Works. WRC Report No. TT 83/97. Water Research Commission, Pretoria.

MKHIZE SP, ATKINSON BW and BUX F (2000) Evaluation of a laboratory-scale biological process for the treatment of edible oil effluent. Water SA 26 (4) 555-558.

SCURAS S, DAIGGER GT and GRADY LCP (1998) Modelling the activated sludge floc environment. Water Sci. Technol. 37 (3) 243250.

SENG WC (1980) Wastewater treatment for edible oil refineries. J. Am. Oil Chem. Soc. 57 (12) 926A-928A.

STANDARD METHODS (1989) Standard Methods for Examination of Water and Wastewater (1 $7^{\text {th }}$ edn). American Public Health Associations, American Water Works Association, Water Pollution Control Federation, USA.

STEFFEN, ROBERTS and KIRSTEN [SRK (CE) Inc.] (1989) Water and Wastewater Management in the Edible Oil Industry. WRC Report No. TT 40/89. Water Research Commission, Pretoria.

THE NATIONAL WATER ACT (1998) The National Water Act, Act 36 of 1998. Internet URL http://www.dwaf.gov.za/documents.

WANNER J, RUZICKOVA I, JETMAROVA P, KRHUTKOVA O and PARANIAKOVA J (1998) A national survey of activated sludge separation problems in the Czech Republic: Filaments, floc characteristics and activated sludge metabolic properties. Water Sci. Technol. 47 (4) $271-279$ 